\title{
Phytochemical and Toxicological Studies of an Extract of the Seeds of Picralima Nitida (Stapf) (Apocynaceae) and Its Pharmacological Effects on the Blood Pressure of Rabbit
}

\author{
Fulgence Kouakou Kouassi N'dri \\ Laboratory of Pharmacognosy \\ Training and Research Unit of Pharmaceutical and Biological Sciences \\ University Felix Houphouët-Boigny, Côte d'Ivoire 01 BP V34 Abidjan 01 \\ E-mail: fulndry@yahoo.fr
}

\begin{abstract}
Semi Anthelme Nene-Bi (Corresponding author)
Laboratory of Animal Physiology, Training and Research Unit of Biosciences

University Felix Houphouët-Boigny, Côte d'Ivoire 22 BP 582 Abidjan 22
\end{abstract}

Tel: 225-0506-8986 E-mail: neneanthelme@gmail.com

Ouga Stanislas Zahoui

Laboratory of Animal Physiology, Training and Research Unit of Biosciences

University Felix Houphouët-Boigny, Côte d'Ivoire 22 BP 582 Abidjan 22

E-mail: s.zahoui@gmail.com

Flavien Traore

Laboratory of Animal Physiology, Training and Research Unit of Biosciences

University Felix Houphouët-Boigny, Côte d'Ivoire 22 BP 582 Abidjan 22

E-mail: traoreff@yahoo.fr

Received: November 14, 2014 Accepted: November 27, 2014

doi:10.5296/jbls.v6i1.6615 URL: http://dx.doi.org/10.5296/jbls.v6i1.6615 


\section{Abstract}

The phytochemical screening of the seeds extracts of Picralima nitida has highlighted the presence of alkaloids and terpenes poly sterols in chloroform solutions, methanol and in the aqueous. Unlike chloroform and methanol solutions, the aqueous revealed the presence of saponins. An acute toxicity study in mice showed that the aqueous extract of Picralima nitida would be slightly toxic with a lethal dose (LD) $50 \%$ of $9120.11 \mathrm{mg} / \mathrm{kg}$ of body weight (bw). This extract, in rabbits induced a dose-dependent hypotension for the doses between $3.10^{-6} \mathrm{~g} /$ $\mathrm{kg}$ bw and $2.10^{-5} \mathrm{~g} / \mathrm{kg}$ bw with an effective dose $50 \%$ (ED50) equal to $4.07 \times 10^{-6} \mathrm{~g} / \mathrm{kg}$ bw. In the presence of atropine $\left(6.10^{-9} \mathrm{~g} / \mathrm{kg}\right)$, a competitive inhibitor of acetylcholine, the hypotensive effect of aqueous extract of Picralima nitida is reduced, confirming in this extract the presence of cholinomimetics substances of muscarinic type. The results therefore suggest the presence of cholinomimetics substances in the aqueous extract of Picralima nitida seed. These substances could be responsible for the hypotensive effect of this extract. The same extract did not induce diuresis in rats.

Keywords: Picralima nitida, Cholinomimetics substances, Atropine

\section{Introduction}

Picralima nitida called Picralima macrocarpa or Picralima kleineana or Tabernaemontana nitida (Omino, 2002) is a traditional medicinal plant widely used in Africa in the treatment of many diseases. It is a deciduous tree of about 20 meters high widespread in intertropical forested areas of Africa from Côte d'Ivoire (Ivory Coast) to Uganda through Zaire. This vegetable species is also found in mature secondary forest. The fruit is broadly abovoid, smooth and glabrous measuring about $15 \mathrm{~cm}$ long and $10 \mathrm{~cm}$ in diameter. Each fruit contains three flattened seeds embedded in pulp (Irvine, 1961; Keay et al., 1964; Adjanohoun et al., 1984, 1996; Shmelzer and Gurib-Fakim, 2008). Picralima nitida is used in traditional medicine for the treatment of diseases like malarial, typhoid fever, anemia, jaundice and dysmenorrheas (Jiofack et al., 2009). The Previous pharmacological studies of this plant extract showed that this plant possess sympathocostenic, antimalarial, antipsychotic and anaesthesic activities equivalent to that of cocaine (Perrot, 1944; Kerharo and Bouquet, 1950; Kapadia et al., 1993; Okunji et $a l ., 2005)$. It would also have antimicrobial, hypoglycemic and antidiarrheal properties (Fakeye et al., 2004; Nkere et al., 2005; Inya-Agha et al., 2006; Kouitcheu et al., 2006; Salihu et al., 2009). Since, some of activities of this substance have not been investigated scientifically. For this, the aim of this study is to provide a phytochemical screening, a toxicological study of extracts Picralima nitida seed and evaluate its pharmacological effects on blood pressure of the rabbit.

\section{Materials and Methods}

\subsection{Plant Material}

The seeds of Picralima nitida were purchased from an herbalist in yopougon market in the north of Abidjan (Ivory Coast). They were identified by an expert in botanic systematic, professor Ake-Assi of the national floristic centre of University Felix Houphouet-Boigny. 


\subsubsection{Preparation of Aqueous Extract of Picralima Nitida Seeds}

The Picralima nitida seeds from dry fruits were ground with micro-crusher (Culatti, France). The powdered $\left(5 \mathrm{~g}\right.$ ) of seed was diluted in $50 \mathrm{ml}$ of boiled distilled water at $100^{\circ} \mathrm{C}$ during 15 minutes. The infused is cooled and the solution obtained was filtered through of wattman paper $\mathrm{n}^{\circ} 1$. The filtrate was frozen at $-30^{\circ} \mathrm{C}$ and lyophilized at $-45^{\circ} \mathrm{C}$ using a lyophilisator (Telstar, Spain). A brown colored powder was obtained. It is stored in the refrigerator at $-5^{\circ} \mathrm{C}$ in a sealed jar.

\subsection{Animal Material}

The animals used in our experiments, consist of mice (Mus musculus), rat (Rattus norvegicus) and rabbit (Oryctolagus cuniculus). The tests were performed only after that, rats were acclimated to the environment of the animal house of Biosciences. All procedures were approved by ethical committee of University Felix Houphouet-Boigny (Ivory Coast) and in accordance with the principles of scientific ethical committee of biology for use of laboratory animals for experimental tests (Aworet-Samseny et al., 2011).

\subsubsection{Mice}

The white mice (Mus musculus), from Swiss stump, weighing 25 to $30 \mathrm{~g}$, were used for toxicological tests.

\subsubsection{Rats}

The Wistar rats (Rattus norvegicus) used for the diuretic activity weighed an average 150-200 g.

\subsubsection{Rabbits}

Only rabbits with a weight equal or greater than $1.45 \mathrm{~kg}$ were used. These animals were used for the measurement for arterial blood pressure.

\subsection{Phytochemical Screening}

The phytochemical screening was done using classic methods (Karumi et al. 2004; Bekro et al., 2007; Nene Bi et al., 2008; Farhat et al., 2011; Soni and Sosa, 2013). Chemical compounds tested in all the extracts of Picralima nitida seeds were: saponosides, alkaloids, flavonoids, tannins, terpenes, sterols, phenols and quinones. The tests were based on the visual observation of color change or formation of a precipitate after specific reactions.

\subsection{Oral Acute Toxicity}

The healthy mice of both sexes were divided into 4 groups of 10 animals. Ten mice of equal numbers of male and female were used and each received a single oral-dose, using an intragastric cannula. Animals were kept overnight fasting prior to drug administration by gavage. The maximum dose volume administered did not exceed $2 \mathrm{ml} / 100 \mathrm{~g}$ body weight. Animals were observed individually at least once during the first 30 minutes after dosing, periodically during 8 hours and daily thereafter, for a total of 14 consecutive days for behavioural changes and mortality. 


\subsection{Recording of Rabbit Blood Pressure}

The experimental device used for recording of the blood pressure in the rabbit is based on the principle of the mercury manometer of Ludwig. The rabbits $(1.45 \mathrm{~kg})$ were anesthetized by intraperitoneal injection of ethyl-urethane $40 \%$ dosed at $1 \mathrm{~g} / \mathrm{kg}$ of body weight (bw). The saphenous vein from the leg was bared. This vein is intubated with a catheter attached to a syringe allowing the injection of different doses of the aqueous extract of Picralima nitida or atropine. For dose-response effect, the extract was administered alone. But to show the presence of cholinomimetic substance in the extract, atropine was administered before the extract. The rabbit carotid artery was exposed and intubated using a catheter connected to a U-tube manometer, which collects directly the intra-carotid pressure. It is the non-invasive method. This method measures the level of reference pressure in rabbits. Changes in the carotid pressure, transmitted to the mercury column of the device are recorded with a pen that translates the movements of mercury on the paper placed on a cylinder driven at constant speed by a motor.

\subsection{Diuretic Activity}

Twenty (20) male rats were used. These rats were divided into five equal groups ( $n=4 /$ group). After 18 hours of total fasting, they received $50 \mathrm{ml} / \mathrm{kg}$ of body weight (bw) of distilled water orally before treatment. To determine their influence on elimination of fluid overload, the excretion of sodium and potassium, the aqueous extract of Picralima nitida and the reference diuretic, the furosemide were administered to rats intraperitoneally. According Gallez et al. (1999), the intraperitoneal administration in rat presents high absorption rate compared to oral administration. This administration mode provides better bioavailability of the test substance in animals. Furosemide (Hoechst Houde, Germany) was purchased from the pharmacy. The animals in the control group were received intraperitoneally saline solution at the dose of $9 \%$. The rats were placed in metabolic cages (one in each cage) specially designed to separate urine and feces and maintained at room temperature. The urine volumes were determined after 24 hours. The concentrations of sodium, potassium in the urine and serum were determined using a flame photometer (optional ISE) with a multiparameter analyzer (Hitachi 902).

\subsection{Statistical Analysis}

The statistical analysis was performed using one-way analysis of variance (ANOVA) of the multiple test of comparison of Tukey-Kramer (GraphPad Prism software, version 4, San Diego, USA). The level of significance was determined in comparison with the control group. $p<0.05$ was considered significant. All values are expressed as mean \pm SEM.

\section{Results}

\subsection{Phytochemical Screening of Picralima Notida Extract}

The qualitative phytochemical analysis of chloroform, methanolic and aqueous extracts allowed to highlight the presence of sterols polyterpenes, alkaloids. In addition to these compounds, saponins have been identified in the aqueous (Table 1). 


\section{Macrothink}

Tableau 1. Phytochemical screening of the extracts of Picralima nitida seeds

\begin{tabular}{|l|l|l|l|}
\hline Chemical components & Chloroform extract & Methanolic extract & Aqueous extract \\
\hline Quinones & - & - & - \\
\hline Catechic tannins & - & - & - \\
\hline Gallic tannins & - & - & - \\
\hline Alkaloids & + & + & + \\
\hline Sterols polyterpenes & + & + & + \\
\hline Polyphenols & - & - & - \\
\hline Flavonoids & - & - & - \\
\hline Saponosides & & & + \\
\hline
\end{tabular}

Absence (-); Présence (+)

\subsection{Toxicological Study}

The oral administration of the aqueous extract of the seeds of Picralima nitida $(P n)$ at the doses ranging from $3408.9 \mathrm{mg} / \mathrm{kg}$ to $13620 \mathrm{mg} / \mathrm{kg}$ of body weight (bw) provokes a decrease of the motor activity in mice. These mice move firstly hardly. These dose-dependent phenomena occur after 20 minutes for doses less than $6810 \mathrm{mg} / \mathrm{kg}$ bw and after 15 minutes for the doses higher than $13620 \mathrm{mg} / \mathrm{kg}$ of the extract. Whatever at the dose of $P n$, these animals are lying upon each other in a corner of the cage. The death of mice was observed for the doses equal or higher than $6810 \mathrm{mg} / \mathrm{kg}$ bw (Table 2) and the lethal dose 50\% (LD50) was determined to be $9120.11 \mathrm{mg} / \mathrm{kg}$ for the graphic method (Figure 1) of Miller and Tainter, or $8852 \mathrm{mg} / \mathrm{kg}$ for calculation method of Karber and Behrens.

Tableau 2. Mortality in mice treated with the aqueous extract of Picralima nitida

\begin{tabular}{|l|l|l|l|}
\hline Groups of mice & Dose of Pn $(\mathrm{mg} / \mathrm{kg}$ bw) & Mortality (\%) & Mortality (probit Unit) \\
\hline I & 3408.9 & 0 & 1.9 \\
\hline II & 4539 & 0 & 1.90 \\
\hline III & 6810 & 30 & 4.47 \\
\hline IV & 13620 & 90 & 6.28 \\
\hline
\end{tabular}

In this study, $P n$ caused the death in mice at the high doses like $6810 \mathrm{mg} / \mathrm{kg}$ bw. 


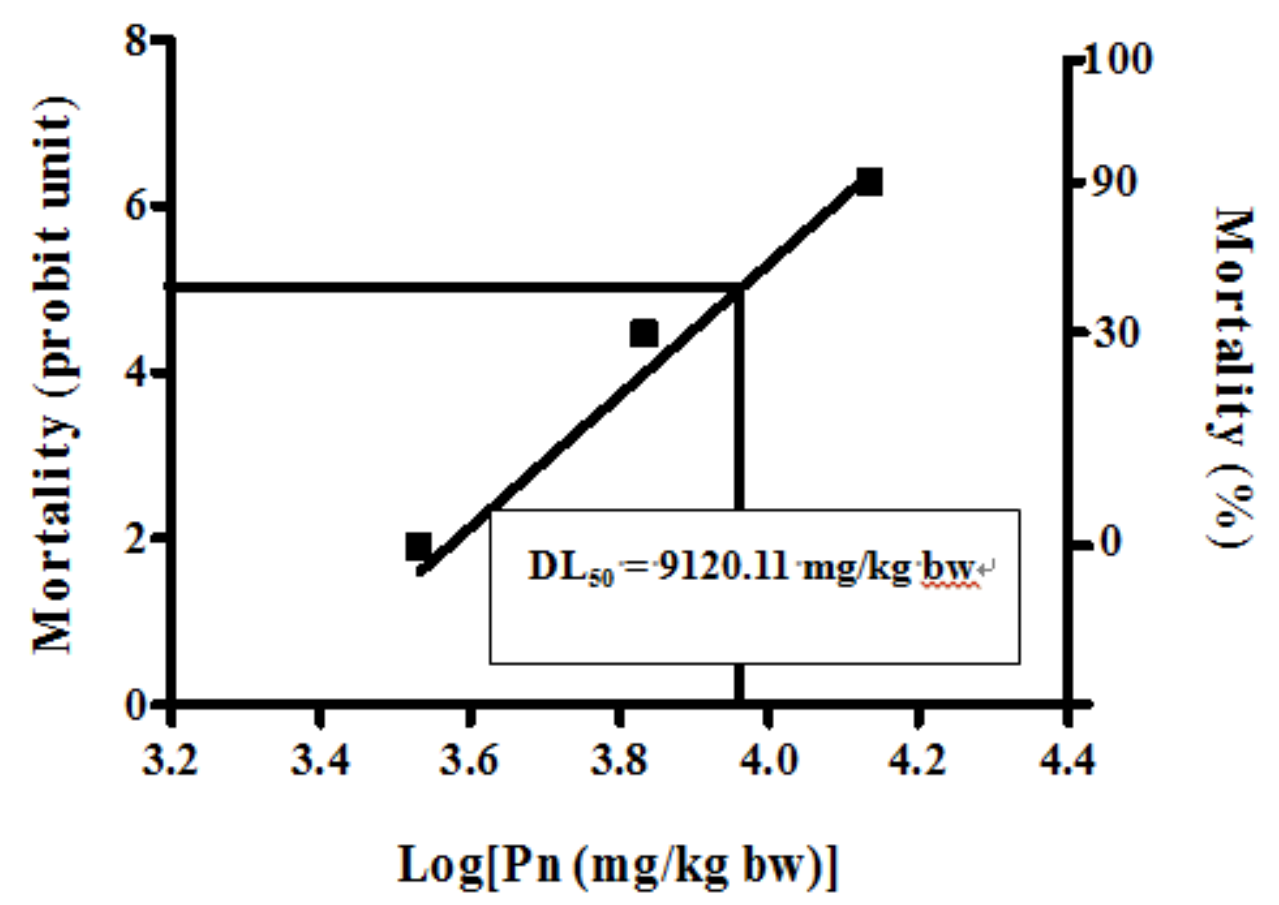

Figure 1. Oral acute toxicity study in mice treated with the aqueous extract of Picralima nitida. In presence of this extract considered slightly toxic, the LD50 was $9120.11 \mathrm{mg} / \mathrm{kg} \mathrm{bw}$.

\subsection{Effect of the Extract of Picralima Nitida on Blood Pressure in Rabbit}

Figure 2A shows an original recording of dose-dependent hypotension induced by Picralima nitida aqueous extract $(P n)$. $P n$ for doses ranging from $3 \times 10^{-6} \mathrm{~g} / \mathrm{kg}$ to $2 \times 10^{-5} \mathrm{~g} / \mathrm{kg}$ bw, provokes a transient hypotension ranging from $20 \mathrm{mmHg}$ to $36 \mathrm{mmHg}$. That corresponds to a decrease of the blood pressure of $39.83 \pm 1.88 \%$ and de $103.33 \pm 6 \%(\mathrm{p}<0.001)$.

In the presence of atropine $\left(6 \times 10^{-9} \mathrm{~g} / \mathrm{kg} \mathrm{bw}\right)$, an antagonist of muscarinic receptor of acetylcholine, the hypotension induced by $P n$ for doses ranging from $3.10^{-6} \mathrm{~g} / \mathrm{kg}$ to $1.2 \times 10^{-5}$ $\mathrm{g} / \mathrm{kg}$ bw (Figure 2B) was reduced respectively from $22.22 \pm 6 \%(\mathrm{p}>0,05)$ to $55.56 \pm 5 \%$ ( $<$ 0,001) (Figure 2C). 
A

1

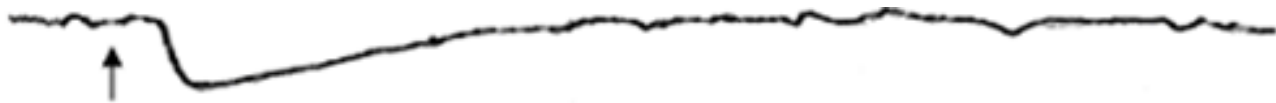

2

Pn $3 \times 10^{-6} \mathrm{~g} / \mathrm{kg}$

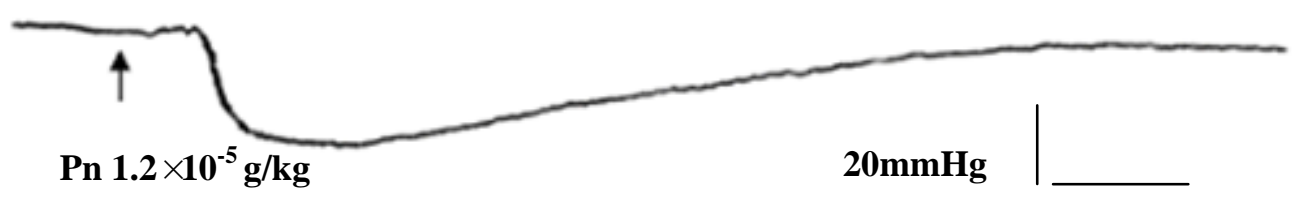

$15 \mathrm{~S}$

1

B

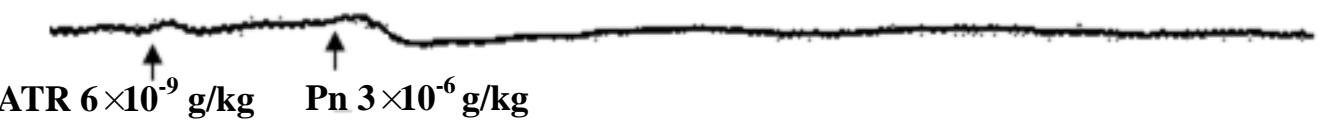

2

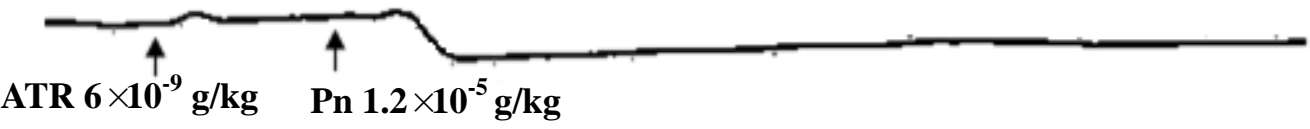

C

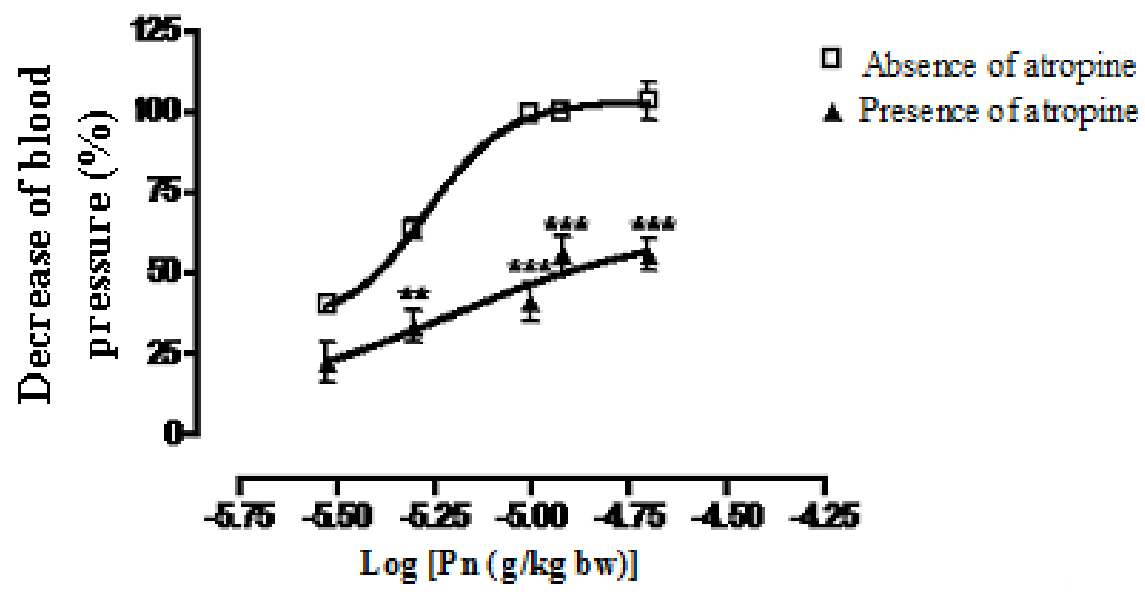

Figure 2. Dose-response effects of Picralima nitida on arterial blood pressure in rabbit. (A) An original recording of the effect of Pn on the arterial blood pressure for doses ranging from $3 \times 10^{-6} \mathrm{~g} / \mathrm{kg}$ (1) to $1.2 \times 10^{-5} \mathrm{~g} / \mathrm{kg}$ bw (2). Pn causes a dose-dependent hypotension in rabbit. (B) The same doses of Pn are tested in presence of atropine $\left(6.10^{-9} \mathrm{~g} / \mathrm{kg}\right)$. This antagonist reduces hypotensive effect of Pn. $(\boldsymbol{C})$ Curves showing a decrease of blood pressure in the rabbit in absence or presence of atropine. Data are shown as means \pm SEM, **p<0.01; ***p $<0.001 ; n$ $=3$.

\subsection{Diuretic Activities}

Doses of $P n$ of $0.21 \mathrm{~g} / \mathrm{kg}$, of $0.42 \mathrm{~g} / \mathrm{kg}$ and of $0.63 \mathrm{~g} / \mathrm{kg}$ bw were used for this study. These doses did not modify significantly $(\mathrm{p}>0.05)$ the urinary volumes measured in treated animals with $P n(18.58 \pm 5.75-7.86 \pm 4.21 \mathrm{ml} / \mathrm{kg})$ compared to that of control $(15.36 \pm 3.93 \mathrm{ml} / \mathrm{kg})$. For the same doses of this extract, the respective concentrations of urinary and plasmatic sodium and potassium were not very different $(p>0.05)$ compared with the control values. 


\section{Discussion}

The results obtained in this study showed that the aqueous extract of the seeds of Picralima nitida contained alkaloids, sterols, polyterpenes and saponosides. These results confirm the previous study done by Perrot (1944), Kerharo and Bouquet (1950), Saxon (1973), Ansa-Asamoah et al. (1990), Kapadia et al. (1993), Duwiejua et al. (2002) and Okunji et al. (2005). These authors showed that this plant contained several alkaloids; the main ones were Akuammine and Akuammidine.

The acute toxicity study of Picralima nitida revealed a LD50 equal to $9120.11 \mathrm{mg} / \mathrm{kg}$ body weight (bw) which would render this plant slightly toxic according the classification of Diezy (1989) for substances. This extract is less toxic than the extracts of Argania spinosa (Dominique and Zoubida, 2005) and Spondiathus preussii (Ibo, 1977) which have lethal dose $50 \%$ respectively equal to $1.3 \mathrm{~g} / \mathrm{kg}$ and $4.43 \mathrm{~g} / \mathrm{kg}$ bw. On the other side, this extract would be more toxic than the extract of Pilostigma reticulatum which had a DL50 of $17 \mathrm{~g} / \mathrm{kg}$ bw (Diallo and Diouf, 2000).

On blood pressure in rabbit, the aqueous extract of the seeds of Picralima nitida for doses ranging from $3 \times 10^{-6} \mathrm{~g} / \mathrm{kg}$ de PC to $1.2 \times 10^{-5} \mathrm{~g} / \mathrm{kg}$ bw, caused a dose-dependent hypotension. Similar hypotensive effects have been reported by Asgary et al. (2000) and Niazmand and Saberi (2010) on Achillea millefolium and Kitic et al. (2012) on Sideritis raeseri.

The hypotensive effect of the extract of the seeds of Picralima nitida reminds the effects of acetylcholine. The use of atropine, a competitive inhibitor of acetylcholine (Gerova et al., 2005; Hirota and McKay, 2006; de Azua et al. 2012; Jain et al., 2012) reduced significantly the dose-dependent hypotension induced by $P n$ in rabbit. It indicates the presence of cholinomimetics substances in this crude extract. These results, comparable to those obtained by Dimo et al. (1999) with Bidens pilosa (Asteraceae), Abo et al. (2000) with Mareya micrantha (Euphorbiaceae) and Konan et al. (2006) with Sesamum radiatum (Pedaliaceae), Atsamo et al. (2013) on Erythrina senegalensis and Boua et al. (2013) on Turraea heterophylla, demonstrates the presence of cholinomimetics substances in the aqueous extract of Picralima nitida.

Indeed, acetylcholine by binding to its muscarinic type receptors on heart, could cause, negative inotropic and chronotropic effects (Felder, 1995; Bois et al., 1999; Roffel et al., 2001; Racke and Matthiesen, 2004; Gerova et al., 2005; Hirota and McKay, 2006) and the vasorelaxation by releasing nitric oxide (NO) by endothelium (Furchgott and Zawadzki, 1980; Zapol et al., 1994; Ducrocq et al., 2001; Zhao et al., 2004; Lamblin et al., 2005; Collin and Levy, 2008; Jeanneret, Sanchez, Liaudet, 2011).

The hypotensive effects of $P n$ could be, probably the combined action of the effects of cardio-inhibitory and vasodilator substances.

If the hypotensive effect of the crude extract of Picralima nitida was demonstrated, this extract does not seem to have diuretic effect like the extracts of Bidens pilosa (Dimo et al., 1999) and Bridelia ferruginea (Nene Bi et al., 2012; 2013). 


\section{Conclusion}

The phytochemical screening of the aqueous extract of the seeds of Picralima nitida revealed the presence of alkaloids, confirming the work of many authors. This extract considered slightly toxic, has hypotensive effects that would be due mainly to the cardio-inhibitors principles antagonized by atropine or not. This result is in agreement with the hypotensive effects of Akuammidine, one of the main alkaloids isolated from Picralima nitida seeds which advocates for the use of this plant in the treatment of hypertension.

\section{References}

Abo, J. C., Aka, K. J. Ehile, E. E., \& Guede-Guina, F. (2000). Effets d'un extrait aqueux de Mareya micrantha et de ses différentes fractions sur l'activité mécanique du cœur isolé de rat. Revue Médecines et Pharmacopées Africaines, 14, 7-14.

Adjanohoun, E. J., Aboubakar, N., Diamante, K., Ebot, M. E., Ekpere, J. A., Enow-Orock, E. G., Focho, D., Gbile, Z. O., Kamanyi, A., Kamsu Kom, J., Keita, A., Mbenkum, T., Mbi, C. N., Mbiele, A. L., Mbome, I. L., Mubiru, N. K., Nancy, W. L., Nkongmeneck, B., Stabie, B., Sofowora, A., Tamze, V., \& Wirmum, C. K. (1996). Contribution to ethnobotanical and floristic studies in Cameroon, Traditional Medecine and Pharmacopoeia. Technical and Research Commission of the Organization of African Unity (OAU/STRC): 60-61.

Adjanohoun, E. J., Aké-Assi, L., Chibon, P., De Vecchy, H., Duboze, E., Eyme, J., Gassita, J. N., Goudote, E., Guinko, S., Keita, A., Koudogbo, B., Le bras, M., Mourambou, I., Mve-Mengonme, E., Nguéma, M. G., Ollome, J. B., Posso, P., \& Sita, P. (1984). Contribution aux études ethnobotaniques et floristiques au Gabon, Agence de Coopération Culturelle et Technique (ACCT), Paris, p.294.

Ansa-Asamoah, R., Kapadia, G. J., Lioyd, H. A., \& Sokoloski, E. A. (1990). Piratidine, a new indole alkaloid from Picralima nitida seeds. Journal of Natural Products, 53(4), 975-977. http://dx.doi.org/10.1021/np50070a032

Asgary, S., Naderi, G. H., Sarrafzadegan, N., Mohammadifard, N., Mostafavi, S., \& Vakili, R. (2000). Antihypertensive and antihyperlipidemic effects of Achillea wilhelmsii. Drugs under experimental and clinical research, 26(3), 89-93.

Atsamo, A. D., Nene-Bi, A. S., Kouakou, L. K., Fofié, C. K., Nyadjeu, P., Watcho, P., Datté, J. Y., Kamanyi, A., \& Nguelefack, T. B. (2013). Cardiovascular and Antioxidant Effects of the Methanol Extract From the Stem Bark of Erythrina Senegalensis DC (Fabaceae). Journal of Physiology and Pharmacology Advances, 3(4), 110-120. http://dx.doi.org/10.5455/jppa.20130430124448

Aworet-Samseny, R. R., Souza, A., Kpahé, F., Konaté, K., \& Datté, J. Y. (2011). Dichrostachys cinerea (L.) Wight et Arn (Mimosaceae) hydro-alcoholic extract action on the contractility of tracheal smooth muscle isolated from guinea-pig. BMC Complementary and Alternative Medicine, 11, 23. http://dx.doi.org/10.1186/1472-6882-11-23

Bekro, Y. A., Bekro, J. A. M., Boua, B. B., Tra Bi, F. H., \& Ehilé, E. E. (2007). Etude 
ethnobotanique et screening phytochimique de Caesalpinia benthamiana (Baill.) Herend et Zarucchi (Caesalpiniaceae). Sciences et Nature, 4(2), 217-225.

Bois, P., Fares, N., Lenfant, J., \& Potreau, D. (1999). Le canal-f cardiaque protéine du rythme et de l'arythmie? Médecine/Sciences, 15, 376-381. http://dx.doi.org/10.4267/10608/1348

Boua, B. B, Mamyrbekova-Bekro, J. A., Kouame, B. A., \& Bekro, Y. A. (2013). Criblage phytochimique et potentiel érectile de Turraea heterophylla de Côte d'Ivoire. Journal of Applied Biosciences, 68, 5394-5403. http://dx.doi.org/10.4314/jab.v68i0.95065

Collin, S., \& Levy, B. (2008). Physiopathologie de l'hyporéactivité vasculaire au cours des états de choc. Réanimation, 17, 101-110. http://dx.doi.org/10.1016/j.reaurg.2007.12.008

Diallo, B., \& Diouf, A. (2000). Etude de l'activité analgésique du Pilostigma reticulatum (Nguiguis). Odonto-stomatologie Tropicale, 92, 5-11.

Diezi, J. (1989). Toxicologie: Principes de base et répercussions cliniques. In Pharmacologie:Des principes fondamentaux aux applications thérapeutiques. Ed. Slatkine-Génève. 33-44.

Dimo, T., Nguelefack, T. B., Kamtchouing, P., Dongo, E., Rakotonirina, A., \& Rakotonirina, S. V. (1999). Effets hypotensifs de l'extrait au méthanol de Bidens pilosa Linn chez les rats hypertendus. Comptes rendus de l'Académie des Sciences, 322, 323-329. http://dx.doi.org/10.1016/S0764-4469(99)80068-7

Dominique, G., \& Zoubiba, C. (2005). Saponines et métabolites secondaires de l'Arganier. Cahier Agriculture, 14(6), 509-516.

Ducrocq, C., Servy, C., Cudic, M., \& Blanchard, B. (2001). Intervention du monoxyde d'azote, NO, et de ses dérivés oxydés, particulièrement chez les mammifères. Canadian Journal of Physiology and Pharmacology, 79(2), 95-102. http://dx.doi.org/10.1139/y00-077

Duwiejua, M., Woode, E., \& Obiri, D. D. (2002). Pseudo-akuammigine, an alkaloide from Picralima nitida seeds, has anti-inflammatory and analgesic actions in rats. Journal of Ethnopharmacology, 81(1), 73-79. http://dx.doi.org/10.1016/S0378-8741(02)00058-2

Fakeye, A., Itiola, O. A., George, A. O., \&. Odelola, H. A. (2004). Antimicrobial property of Picralima nitida stem bark extract in cream formulations. Pharmaceutical Biology, 42(4-5), 274-279. http://dx.doi.org/10.1080/13880200490511765

Farhat, A. K., Iqbal, H., Shahid, F., Majed, A., Muhammad, A., \& Inayat, U. R. (2011). Phytochemical Screening of Some Pakistanian Medicinal Plants. Middle-East Journal of Scientific Research, 8(3), 575-578

Felder, C. C. (1995). Muscarinic acetylcholine receptors: signal transduction through multiple effectors. Journal of the Federation of American Societies for Experimental Biology, 9, 619-625.

Furchgott, R. F., \& Zawadski, J. V. (1980). The obligatory role of endothelial cells in the relaxation of arterial smooth muscle by acetylcholine. Nature, 288, 373-376. 
http://dx.doi.org/10.1038/288373a0

Gallez, B., Demeure, R., Baudelet, C., Geurts, M., Geubel, A., Roels, H. (1999). Evaluation par RMN de l'intoxication cérébrale par le manganèse. Louvain Médical, 118, 165-168.

Gerova, M., Kristek, F., Cacanyiova, S., \& Cebova, M. (2005). Acetylcholine and bradykinin enhance hypotension and affect the function of remodeled conduit arteries in SHR and SHR treated with nitric oxide donors. Brazilian Journal of Medical and Biological Research, 38, 959-966. http://dx.doi.org/10.1590/S0100-879X2005000600019

Hirota, C. L., \& Mckay, D. M. (2006). M3 muscarinic receptor-deficient mice retain bethanechol-mediated intestinal ion transport and are more sensitive to colitis. Canadian Journal of Physiology and Pharmacology, 84(11), 1153-1161. http://dx.doi.org/10.1139/y06-068

Ibo, C. A. (1977). Contribution à l'étude des plantes toxiques de Côte d'Ivoire. Etude de la toxicité de Jartropha curcas (Euphorbiaceae) et Rauwolfia vomitoria (Apocynaceae). Thèse de Diplôme d'Etat de Docteur en Pharmacie, Université d'Abidjan- Cocody, p.86.

Inya-Agha, S. I., Ezea, S. C., \& Odukoya, O. A. (2006). Evaluation of Picralima nitida: Hypogycemic activity, Toxicity and Analytical Standards. International Journal of Pharmacology, 2(5), 786-580.

Irvine, F.R. (1961). Woody plant of Ghana, Oxf. University Press: London; 629 - 630.

Jain, G., Bodakse, S. H., Namdev, K., Rajput, M. S., \& Mishra, S. (2012). Development of an ex vivo model for pharmacological experimentation on isolated tissue preparation. Journal of Advanced Pharmaceutical Technology and Research, 3(3), 176-181. http://dx.doi.org/10.4103/2231-4040.101013

Jeanneret, S., Sanchez, B., \& Liaudet, L. (2011). Physiopathologie et traitement de la vasoplégie au cours du sepsis. Revue Médicale Suisse, 7, 2435-2438.

Jiofack, T., Ayissi, I., Fokunang, C., Guedje, N., \& Kemeuze, V. (2009). Ethnobotany and phytomedicine of the upper Nyong valley forest in Cameroon. African Journal of Pharmacy and Pharmacology, 3(4), 144-150.

Kapadia, G. J., Angerhofer, C. K., \& Ansa-Asamoah, R. (1993). Akuamine: un antipaludique indoloterpène, alcaloide des graines de Picralima nitida. Planta Medica, 59(6), 565-566. http://dx.doi.org/10.1055/s-2006-959764

Karumi, Y., Onyeyili, P. A., \& Ogugbuaja, V. O. (2004). Identification of active principles of M. balsamina (Balsam Apple) leaf extract. Journal Medical Sciences, 4(3), 179-182. http://dx.doi.org/10.3923/jms.2004.179.182

Keay, R. W. J., Onochie, C. F. A., \& Stemfield, D. D. (1964). Nigerian Trees, Ibadan Federal Dept. Of Forest Res: Ibadan, 2, 378-396.

Kerharo, J., \& Bouquet, A. (1950). Plantes médicinales et toxiques de la Cote d'Ivoire-Haute-Volta. Editions Vigot Frères, P.2995. 
Kitic, D., Brankovic, S., Radenkovic, M., Savikin, K., Zdunic, G., Kocic, B., \& Velickovic Radovanovic, R. (2012). Hypotensive, vasorelaxant and cardiodepressant activities of the ethanol extract of Sideritis raeseri spp. raeseri boiss \& heldr. Journal of Physiology and Pharmacology, 63(5), 531-535

Konan, B. A., Datté, Y. J., \& Offoumou, A. M. (2006). Action de l'extrait aqueux de Sesamum radiatum (Pedaliaceae) sur le système cardiovasculaire de mammifères: effet hypotenseur. Current Bioactive Compounds, 2(5), 263-267.

Kouitcheu, M. L. B., Penlap, B. V., Kouam, J., Ngadjui, B. T., Fomum, Z. T., \& Etoa, F. X. (2006). Evaluation of antidiarrhoeal activity of the fruit-rind of Picralima nitida (Apocynaceae). African Journal of Traditional, Complementary and Alternative medicines, 3(4), 66-73.

Lamblin, N., Cuilleret, F. J., Helbecque, N., Dallongeville, J., Lablanche, J. M., Amouyel, P., Bauters, C., \& Van Belle, E. (2005). A common variant of endothelial nitric oxide synthase (Glu298Asp) is associated with collateral development in patients with chronic coronary $\begin{array}{lllll}\text { occlusions. } & B M C & \text { Cardiovascular } & \text { Disorders, } & 53\end{array}$ http://dx.doi.org/10.1186/1471-2261-5-27

Nene-Bi, S. A., Traore, F., Zahoui, O. S., \& Soro, Y. T. (2008). Composition Chimique d'un extrait aqueux de Bridelia ferruginea benth. (Euphorbiaceae) et étude de ses effets toxicologique et pharmacologiques chez les Mammifères. Afrique Science, 4(2), 287-305.

Nene-Bi, S. A., Soro, T. Y., Zahoui, O. S., Bleu, G. M., Ehoussou, N. C., \& Traore, F. (2013). Effects of Aqueous Extract of Bridelia ferruginea Benth on the Kinetic of Water Overload Elimination in Normal Rat. Electronic Journal of Biology, 09(3), 53-56.

Nene-Bi, S.A., Zahoui, O. S., Soro, T. Y., \& Traore, F. (2012). Diuretic and Natriuretic Activity of an Aqueous Extract of Bridelia Ferruginea Benth. (Euphorbiaceae) in Normal Rats. Journal of Physiology and Pharmacology Advances, 2(10), 349-353.

Niazmand, S., \& Saberi, Z. (2010). The Chronotropic and Inotropic Effects of Aqueous-Ethanolic Extract of Achillea Millefolium on Rat's Isolated Heart. Pharmacologyonline, 3, 791-798.

Nkere, C. K., \& Iroegbu, C. U. (2005). Antimicrobial property of Picralima nitida stem and roots bark extract. African Journal of Biotechnology, 4(6), 522-526.

Okunji, C. O., Iwu, M. M., Ito, Y., \& Smith, P. L. (2005). "Preparative separation of indole alkaloids fromthe rind of Picralima nitida (Stapf) T. Durand \& H. Durand by $\mathrm{pH}$-zone-refining counter current chromatography. Journal of Liquid Chromatography and Related Technologies, 28(5), 775-783. http://dx.doi.org/10.1081/JLC-200048915

Omino, E. A. (2002). Flora of tropical East Africa: Apocynaceae Part 1. Rotterdam: Balkema, p.116.

Perrot, E. (1944). Matières premières usuelles du règne végétal. Thérapeutique-Hygiène industrie. Edition Masson et Cie tome 2, p.243. 


\section{Macrothink}

Journal of Biology and Life Science ISSN 2157-6076 2015, Vol. 6, No. 1

Racke, K., \& Matthiesen, S. (2004). The airway cholonergic system: physiology and pharmacology. Pulmonary Pharmacology and Therapeutics, 17, 181-198. http://dx.doi.org/10.1016/j.pupt.2004.03.001

Roffel, A. F., Meurs, H., \& Zuagsma, J. (2001). Progress in inflammation research muscarinic receptosrs in the airways. In Identification, localization and function of muscarinic receptor subtype in the airways. Basel Birkhäuser, pp63-85.

Ruiz de Azua, I., Gautam, D., Jain, S., Guettier, J. M., \& Wess, J. (2012). Critical metabolic roles of $\beta$-cell M3 muscarinic acetylcholine receptors. Life Science, 91(21-22), 986-991. http://dx.doi.org/10.1016/j.lfs.2012.04.010

Salihu, A., Olayaki, L. A., Oshiba, J. O., Rabiu, J. O., Sikiru, J. A., Olawepo, A., \& Abioye, A. I. (2008). Etude comparative des effets hypoglycémique de l'extrait aqueux des graines de Picralima nitida et du Daonil. African Journal of Biotechnology, 8(4), 574-576.

Saxon, J. E. (1973). Alkaloids of Picralima nitida and Alstonia species. The alkaloids-Chemistry and physiology. Ed. R. H. F. Manske. Academic Press, New York: 157-159.

Schmelzer, G. H., \& Gurib-Fakim, A. (2008). Ressources végétales de l'Afrique tropicale 11 (1). Plantes médicinales 1, p.869.

Soni, A., \& Sosa, S. (2013). Phytochemical Analysis and Free Radical Scavenging Potential of Herbal and Medicinal Plant Extracts. Journal of Pharmacognosy and Phytochemistry, 2(4), 22-29.

Zapol, W. M., Falke, K. J., Hurford, W. E., \& Roberts, J. D. (1994). Inhaling nitric oxide - A selective pulmonary vasodilator and bronchodilator. American Journal of Respiratory and Critical Care Medicine, 149, 1375-1380. http://dx.doi.org/10.1164/ajrccm.149.5.8173780

Zhao, L., Zhang, F., Guo, J., Yang, Y., LI, B., \& Zhang, L. (2004). Nitric oxide functions as a signal in salt resistance in the calluses from two ecotypes of reed. Plant Physiology, 134(2), 849-857. http://dx.doi.org/10.1104/pp.103.030023

\section{Copyright Disclaimer}

Copyright for this article is retained by the author(s), with first publication rights granted to the journal.

This is an open-access article distributed under the terms and conditions of the Creative Commons Attribution license (http://creativecommons.org/licenses/by/3.0/). 